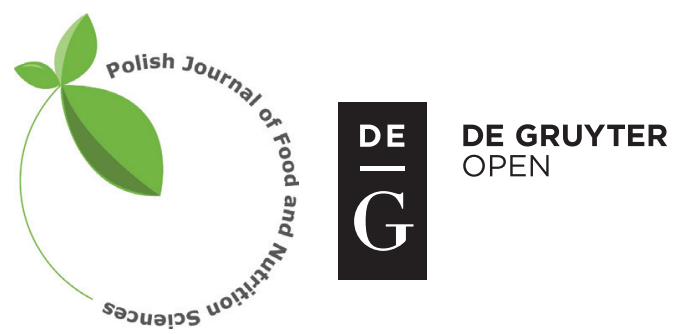

Pol. J. Food Nutr. Sci., 2018, Vol. 68, No. 1, pp. 25-31

DOI: $10.1515 /$ pjfns-2017-0027 http://journal.pan.olsztyn.pl

Original research article

Section: Food Quality and Functionality

\title{
Physical Properties of Buckwheat Water Biscuits Formulated from Fermented Flours by Selected Lactic Acid Bacteria
}

\author{
Matgorzata Wronkowska ${ }^{*}$, Tomasz Jeliński², Anna Majkowska ${ }^{3}$, Henryk Zieliński ${ }^{1}$ \\ ${ }^{1}$ Department of Chemistry and Biodynamics of Food \\ ${ }^{2}$ Department of Chemical and Physical Properties of Food \\ ${ }^{3}$ Microbiological Laboratory \\ Institute of Animal Reproduction and Food Research, Polish Academy of Sciences, 10 Tuwima Str., 10-748 Olsztyn, Poland
}

Key words: buckwheat, fermentation, lactic acid bacteria, hardness, color

The growth of lactic acid bacteria during liquid-state fermentation of buckwheat flour and changes in pH during the process were analyzed. Eight strains of Lactobacillus were selected as the most active strains used to obtain new fermented flours. Physical properties of buckwheat water biscuits formulated from these fermented flours were studied.

The hardness of freshly prepared biscuits was affected by the lactic acid bacteria applied, with its highest value noted for the water biscuits made of buckwheat flour fermented by L. plantarum IB. Significantly greater differences in hardness values of water biscuits were noted after 24 h storage. Moreover, water biscuits made of the fermented flours were lighter and had a higher browning index as compared to the control biscuits prepared from unfermented buckwheat flour. The obtained results demonstrate the feasibility of selecting lactic acid bacteria for the fermentation of buckwheat flour focusing on some physical properties of the water biscuits.

\section{INTRODUCTION}

Buckwheat is a good source of saccharides, well-balanced proteins, vitamins, minerals and different biologically-active compounds [Wronkowska et al., 2010]. There is some evidence indicating that consumption of buckwheat is associated with a wide range of biological and pharmacological activities [Gimenez-Bastida \& Zieliński, 2015a]. Another potential for the development of buckwheat-based products, other than the anticipated health benefits, is the gluten-free market [Giménez-Bastida et al., 2015b]. Varieties of gluten-free products have to be extended for coeliac patients to allow them to keep a balanced diet. One possibility is to replace wheat flour in products by gluten-free ingredients, like e.g. corn and potato starch in tulumba dessert [Yildiz and Bulut, 2017] or rice in white bread [Lopez et al., 2004]. Buckwheat flour significantly improves the overall sensory quality of gluten-free bread and delays its staling as presented by Wronkowska et al. [2013]. It was also used to obtain gluten-free muffins [Ciesarová et al., 2016].

Fermentation could be applied to plant-based foods to increase their nutritional quality or to remove undesirable compounds [Frias et al., 2005]. Lactic acid bacteria (LAB) may improve the quality of fermented products by producing some

\footnotetext{
* Corresponding Author: Fax: +48 89 5240124;

E-mail: m.wronkowska@pan.olsztyn.pl (Dr. M. Wronkowska)
}

substances like alcohols, organic acids, carbonyl substances, and others that influence their taste and flavor. During fermentation, exopolysaccharides are produced that improve the texture of the finished products [Kocková et al., 2013a]. Buckwheat mash could reveal potential for lactic acid fermentation and could be used as a vehicle for probiotics in milk-based products, as presented Matejčeková et al. [2017]. These authors proposed a new buckwheat product with a probiotic potential as an ingredient of a diet for patients suffering from coeliac disease or as a new component of a balanced diet for normal subjects.

Considering the above reports, the aim of this study was to select the most active lactic acid bacteria strains for buckwheat fermented flours production and to evaluate hardness and color of water biscuits formulated from these fermented flours.

\section{MATERIAL AND METHODS}

Commercial Polish common buckwheat (Fagopyrum esculentum Moench) flour was purchased from a local producer (Melvit S.A., Kruki, Poland). Its carbohydrate, dietary fibre, protein, and fat contents were: $62 \mathrm{~g} / 100 \mathrm{~g}$ dry matter (d.m.), $2.3 \mathrm{~g} / 100 \mathrm{~g}$ d.m., $7.2 \mathrm{~g} / 100 \mathrm{~g}$ d.m., and $0.7 \mathrm{~g} / 100 \mathrm{~g}$ d.m., respectively. The content of soluble proteins of flour was determined using the bicinchoninic acid (BCA) protein microassay [Smith et al., 1985] in modification proposed by Horszwald 
et al. [2009]. Briefly, aliquots of $25 \mu \mathrm{L}$ of blank, standard, or appropriately diluted samples were added to $200 \mu \mathrm{L}$ of a BCA solution $\left(\mathrm{BCA}: \mathrm{CuSO}_{4} \times 5 \mathrm{H}_{2} \mathrm{O}, 50: 1, \mathrm{v} / \mathrm{v}\right)$. The mixture was incubated at $37^{\circ} \mathrm{C}$ for $30 \mathrm{~min}$, and absorbance was read at $\lambda=562 \mathrm{~nm}$. The standard curve was plotted within the range of $0.03-1.0 \mathrm{mg} / \mathrm{mL}$ bovine serum albumin (Sigma, Saint Louis, MO, USA). Data were expressed as mg protein/g d.m.

Buckwheat flour was pre-treated before the fermentation process: about $50 \mathrm{~g}$ of flour were suspended in $950 \mathrm{~mL}$ of distilled water; next, the suspension was heated at $90^{\circ} \mathrm{C}$ for 45 min under continuous stirring, then autoclaved at $121^{\circ} \mathrm{C} / 15 \mathrm{~min}$, and finally cooled to $37^{\circ} \mathrm{C}$. The pre-treatment was carried out to reduce microbial populations in buckwheat flour before fermentation, since they would compete with and inhibit the growth of inoculated microbes during the fermentation process. Buckwheat flour pre-treated, but not subjected to the fermentation process was used as a control. Fourteen strains of lactic acid bacteria, listed in Table 1, were subjected to a preliminary analysis which examined their suitability for buckwheat flour fermentation. Eight of them were selected for further investigation: L. acidophilus (145, La5, V, respectively), L. casei LcY, L. plantarum (W42, IB, respectively), L. rhamnosus 8/4, and L. salivarius AWH.

The $5 \%$ suspensions of buckwheat flour in distilled water were inoculated with selected lactic acid bacteria with the amount of $8.00 \log \mathrm{cfu} / \mathrm{mL}$, and fermentation was carried out at $37^{\circ} \mathrm{C}$ for $24 \mathrm{~h}$. Total counts of the analyzed Lactobacillus were determined on the MRS agar (de Man, Rogosa and Sharpe, Merck, No 1.10660.0500). Samples were incubated anaerobically at $37^{\circ} \mathrm{C}$ for $72 \mathrm{~h}$ with the use of the Anaerocult C system (Merck, No 116275). The total count of Streptococcus thermophilus MK-10 was determined on the M-17 agar (Terzaghi and Sandine, Merck, No 1.10660.0500). Samples were incubated aerobically at $37^{\circ} \mathrm{C}$ for $48 \mathrm{~h}$. All strains were from own collection of the Microbiological Laboratory of IAR\&FR PAS Olsztyn, Poland. After fermentation, the samples were freeze-dried (Christ - Epsilon 2-6D LSC plus, Osterode am Harz, Germany).

The $\mathrm{pH}$ value of flour suspensions before and after fermentation was measured with a portable HI 9025C microprocessor (HANNA Instruments, Woonsocket, Rhode Island, USA).

The water biscuit dough was prepared according to the AACC 10-52 method [1995], with the modification proposed by Hidalgo \& Brandolini [2011]. A preliminary water biscuits trail was performed in different temperatures and times. The baking temperature of $220^{\circ} \mathrm{C}$ and time of $30 \mathrm{~min}$ used in this study were selected based on a noticeable change in the browning index of the baked product, within the range of 20-40. The dough was cut with a square cookie cutter $(60 \mathrm{~mm})$.

The hardness of fresh and $24 \mathrm{~h}$-stored water biscuits was determined based on the biscuit penetration test made on a TA.HDPlus texture analyzer with TPA Exponent Software (Stable Micro Systems Ltd., Surray, UK) equipped with a 5-kg load cell. During the experiment, once the trigger force of $5 \mathrm{~g}$ has been attained, a 2-mm cylinder probe $(\mathrm{P} / 2)$ proceeds to penetrate the sample to the distance of $3 \mathrm{~mm}$. The selected settings of the analysis were as follows: pre-test/test/post-test speed, 1.0/0.5/10 mm/s. At least three replicates, obtained from three separate baking processes for every formulation, were analyzed for each type of biscuits and storage time.

The instrumental measurement of water biscuits color was carried out with a ColorFlex Spectrophotometer (HunterLab, Reston, VA, USA), the results were expressed in accordance with the CIELab system with reference to illuminant D65 and an observer angle of $10^{\circ}$. The parameters determined were: $\mathrm{L}^{*}\left(\mathrm{~L}^{*}=0\right.$ [black] and $\mathrm{L}^{*}=100$ [white]), $\mathrm{a}^{*}$ $\left(-a^{*}=\right.$ greenness and $+a^{*}=$ redness $)$ and $b^{*}\left(-b^{*}=\right.$ blueness and $+b^{*}=$ yellowness). The browning index (BI) was calculated using $\mathrm{L}^{*}, \mathrm{a}^{*}, \mathrm{~b}^{*}$ according to Mohammadi et al. [2008]: $\mathrm{BI}=[100(\mathrm{x}-0.31)] / 0.17$, where $\mathrm{x}=\left(\mathrm{a}^{*}+1.75 \mathrm{~L}^{*}\right) /\left(5.645 \mathrm{~L}^{*}\right.$ $\left.+\mathrm{a}^{*}-0.3012 \mathrm{~b}^{*}\right)$.

The measurements were performed in at least three replications for each type of water buckwheat biscuits obtained from three separate baking processes for every formulation. The reported data are the mean results for each formulation with the standard deviation. The results were analyzed by one-way ANOVA. The Fisher's Least Significant Difference Test at a significance level of $\mathrm{p}<0.05$ was performed for post-hoc ANOVA and Pearson's test was used for correlation analysis (STATISTICA for Windows, StatSoft Inc., Tulsa, OK, USA, 2001).

\section{RESULTS AND DISCUSSION}

Cereals are good sources of nutrients for a number of species of the Lactobacillus genus [Muller et al., 2001]. The type of cereal or pseudo-cereal and its chemical composition play a key role in the fermentation process.

Growth of Lactobacillus and Streptococcus thermophilus MK-10 strains in a 5\% suspension of buckwheat flour expressed as the total colony count $(\log \mathrm{cfu} / \mathrm{mL})$ as well as changes in $\mathrm{pH}$ during the fermentation process are compiled in Table 1 . After $24 \mathrm{~h}$ of fermentation, the microbial cell counts reached $9.00 \log \mathrm{cfu} / \mathrm{mL}$ only in seven out of the fourteen analyzed strains of lactic acid bacteria. The highest total colony count was noticed for the sample fermented by L. rhamnosus GG $(8.42 \log \mathrm{cfu} / \mathrm{mL})$. The $\mathrm{pH}$ values determined for the $5 \%$ of buckwheat flour suspension before fermentation ranged from 6.41 (L. salivarius AWH) to 6.66 (control sample). Generally, a significant decrease of $\mathrm{pH}$ was observed for all analyzed strains after 24-h fermentation. The lowest value of $\mathrm{pH}$ (4.22) and the highest $\Delta \mathrm{pH}$ was found for buckwheat flour fermented by L. salivarius AWH (Table 1) $(\mathrm{p}<0.05)$. The change in $\mathrm{pH}$ value of the medium the strains were analyzed in was clearly dependent on the bacterial species. The largest values were noticed for the species L. salivarius, L. acidophilus, and L. plantarum. But for example, the L. casei species, represented in our studies by strains $L$. casei $2 \mathrm{~K}$ and LcY, has used buckwheat flour differently as a substrate. The total colony count after fermentation of both strains was similar, but the $\Delta \mathrm{pH}$ was nearly four times higher for $L$. casei LcY strain.

The presented results are in accordance with literature data. Kocková et al. [2013b] showed that buckwheat flour is a good substrate for a probiotic strain L. rhamnosus GG during ten-hour fermentation, but not as good as barley, rye or amaranth flours. Pelikánová et al. [2015] found that lactoba- 
TABLE 1. Total colony counts of Lactobacillus and Streptococcus thermophilus MK-10 strains in a 5\% suspension of buckwheat flour before and after fermentation and changes of flour $\mathrm{pH}$ during fermentation process.

\begin{tabular}{|c|c|c|c|c|c|}
\hline \multirow{2}{*}{ Specification } & \multicolumn{2}{|c|}{ Before fermentation } & \multicolumn{3}{|c|}{ After fermentation } \\
\hline & $\begin{array}{c}\text { total count } \\
(\log \mathrm{cfu} / \mathrm{mL})\end{array}$ & $\mathrm{pH}$ & $\begin{array}{c}\text { total count } \\
\text { (log cfu/mL) }\end{array}$ & $\mathrm{pH}$ & $\Delta \mathrm{pH}$ \\
\hline Control & & $6.66 \pm 0.01^{\mathrm{a}}$ & & $6.65 \pm 0.01^{\mathrm{a}}$ & $0.01 \pm 0.01^{\mathrm{e}}$ \\
\hline L. acidophilus 145 & $6.99 \pm 0.01^{\mathrm{bc}}$ & $6.45 \pm 0.03^{\text {cde }}$ & $7.93 \pm 0.06^{\mathrm{c}}$ & $4.49 \pm 0.12^{\mathrm{d}}$ & $1.96 \pm 0.11^{\mathrm{b}}$ \\
\hline L. acidophilus La5 & $6.89 \pm 0.07^{c}$ & $6.50 \pm 0.06^{\mathrm{cd}}$ & $7.14 \pm 0.12^{\mathrm{f}}$ & $4.45 \pm 0.14^{\mathrm{d}}$ & $2.05 \pm 0.15^{\mathrm{ab}}$ \\
\hline L. acidophilus V & $6.95 \pm 0.12^{\mathrm{c}}$ & $6.60 \pm 0.05^{\mathrm{ab}}$ & $7.93 \pm 0.10^{c}$ & $4.49 \pm 0.16^{\mathrm{d}}$ & $2.11 \pm 0.11^{\mathrm{ab}}$ \\
\hline L. casei $2 \mathrm{~K}$ & $7.19 \pm 0.09^{\mathrm{b}}$ & $6.42 \pm 0.11^{\mathrm{de}}$ & $8.08 \pm 0.11^{\mathrm{bc}}$ & $5.87 \pm 0.09^{b}$ & $0.55 \pm 0.16^{\mathrm{d}}$ \\
\hline L. casei $\mathrm{LcY}$ & $7.11 \pm 0.09^{\mathrm{b}}$ & $6.46 \pm 0.07^{\mathrm{cde}}$ & $8.15 \pm 0.08^{\mathrm{b}}$ & $4.48 \pm 0.06^{\mathrm{d}}$ & $1.98 \pm 0.02^{\mathrm{b}}$ \\
\hline L. delbrueckii subsp. bulgaricus 151 & $6.85 \pm 0.04^{\mathrm{d}}$ & $6.52 \pm 0.07^{\mathrm{bc}}$ & $7.40 \pm 0.08^{\mathrm{e}}$ & $5.99 \pm 0.14^{\mathrm{b}}$ & $0.53 \pm 0.10^{\mathrm{d}}$ \\
\hline L. delbrueckii subsp. bulgaricus $\mathrm{K}$ & $6.98 \pm 0.08^{\mathrm{bc}}$ & $6.47 \pm 0.06^{\text {cde }}$ & $7.87 \pm 0.04^{\mathrm{cd}}$ & $6.04 \pm 0.09^{b}$ & $0.43 \pm 0.15^{\mathrm{d}}$ \\
\hline L. rhamnosus $8 / 4$ & $6.83 \pm 0.07^{\mathrm{d}}$ & $6.46 \pm 0.08^{\text {cde }}$ & $8.24 \pm 0.13^{\mathrm{b}}$ & $4.50 \pm 0.05^{\mathrm{d}}$ & $1.96 \pm 0.09^{\mathrm{b}}$ \\
\hline L. plantarum $\mathrm{IB}$ & $7.04 \pm 0.10^{\mathrm{bc}}$ & $6.43 \pm 0.05^{\text {de }}$ & $7.52 \pm 0.12^{\mathrm{e}}$ & $4.42 \pm 0.11^{\mathrm{d}}$ & $2.01 \pm 0.12^{\mathrm{ab}}$ \\
\hline L. plantarum $\mathrm{W} 42$ & $6.92 \pm 0.01^{\mathrm{c}}$ & $6.46 \pm 0.05^{\text {cde }}$ & $7.81 \pm 0.09^{\mathrm{d}}$ & $4.46 \pm 0.13^{\mathrm{d}}$ & $2.00 \pm 0.13^{\mathrm{ab}}$ \\
\hline L. rhamnosus GG & $7.49 \pm 0.01^{\mathrm{a}}$ & $6.44 \pm 0.04^{\text {cde }}$ & $8.42 \pm 0.13^{\mathrm{a}}$ & $5.95 \pm 0.13^{\mathrm{b}}$ & $0.49 \pm 0.15^{\mathrm{d}}$ \\
\hline L. rhamnosus $\mathrm{K}$ & $6.98 \pm 0.07^{\mathrm{bc}}$ & $6.45 \pm 0.04^{\text {cde }}$ & $7.86 \pm 0.06^{\mathrm{cd}}$ & $5.90 \pm 0.08^{b}$ & $0.55 \pm 0.12^{\mathrm{d}}$ \\
\hline L. salivarius AWH & $7.00 \pm 0.07^{\mathrm{bc}}$ & $6.41 \pm 0.08^{\mathrm{e}}$ & $8.18 \pm 0.15^{b}$ & $4.22 \pm 0.09^{\mathrm{e}}$ & $2.19 \pm 0.04^{\mathrm{a}}$ \\
\hline S. thermophilus MK-10 & $6.93 \pm 0.04^{c}$ & $6.49 \pm 0.04^{\text {cde }}$ & $7.57 \pm 0.01^{\mathrm{e}}$ & $5.41 \pm 0.03^{\mathrm{c}}$ & $1.08 \pm 0.03^{c}$ \\
\hline
\end{tabular}

Data expressed as mean \pm standard deviation. Values followed by the same letter in the same column (a-e) are not significantly different ( $\mathrm{p}>0.05$ ).

cilli reached a high cell population, accounting for $10^{8} \mathrm{cfu} / \mathrm{mL}$ in the case of buckwheat mashes subjected to 8-hour lactic acid fermentation. While Santos et al. [2014] demonstrated that $12 \mathrm{~h}$ fermentation was required to reach a $\mathrm{pH}$ value of 4.3 during co-culture fermentation of peanut-soy milk.

As indicated in the introduction section, there were attempts to use buckwheat flour as a component of bakery and pastry products [Wronkowska et al, 2013; Ciesarová et al., 2016]. But as shown in a review article by Gallagher et al. [2004], the application of raw pseudocereal flours for baking products is technologically quite difficult due to poor baking performance and poor sensory characteristics. As presented by Coda et al. [2010, 2011], lactic acid bacteria fermentation of these alternative flours could improve baking and sensory qualities and also provide an opportunity of increasing contents of some nutrients.

That is why in our research eight strains were selected after the initial screening of lactic acid bacteria strains for their ability to ferment the buckwheat flour. The largest total colony count of bacteria and a significant decrease in $\mathrm{pH}$ were the main criteria for the selection of bacteria type for further analysis. Strains: $L$. acidophilus (145, La5, V, respectively), $L$. casei LcY, L. plantarum (W42, IB, respectively), L. rhamnosus $8 / 4$, and $L$. salivarius AWH were used to produce fermented buckwheat flours and then to prepare water biscuits to analyze some of their physical properties.

One of the best models to study the effect of fermentation on some physical changes of buckwheat flour is water biscuits [Hidalgo \& Brandolini, 2011]. The water biscuits were obtained using only buckwheat flour and water, without the addition of shortening or other fat and protein sources usually employed in biscuit production. The shape of the water biscuits obtained in this study after baking resembled a pillow, with the air space inside being an unexpected result (Figure 1). The surface of biscuits from the fermented buckwheat flours was nice, glossy and smooth. Only control water biscuits, made of the unfermented pre-treated buckwheat flour, did not have a smooth surface.

The content of soluble proteins and hardness of freshly prepared water biscuits was significantly dependent on the lactic acid bacteria applied (Table 2). The highest content of soluble proteins was found in water biscuits made of buckwheat flour fermented by L. plantarum IB $(45.25 \mathrm{mg} / \mathrm{g}$ d.m.), and the lowest in biscuits made of flour fermented by $L$. acidophilus $V(33.82 \mathrm{mg} / \mathrm{g} \mathrm{d}$ d.m.). Generally, a decrease was observed in the content of soluble proteins in all analyzed water biscuits compared to the control sample. Only for two biscuits made of flour fermented by $L$. plantarum IB and $L$. acidophilus La5 was the content of soluble proteins higher or comparable to that of the control sample. The soluble protein profile depends on fermentation time and the strains used as shown by Ouoba et al. [2003] during the fermentation of African locust bean by strains of Bacillus subtilis and B. pumilus. As presented by Chavan et al. [1988], after $24 \mathrm{~h}$ of natural fermentation of sorghum almost 2-fold increase of soluble proteins content was found compared to the control sample.

The highest hardness was determined for biscuits from buckwheat flour fermented by L. plantarum IB and W42 

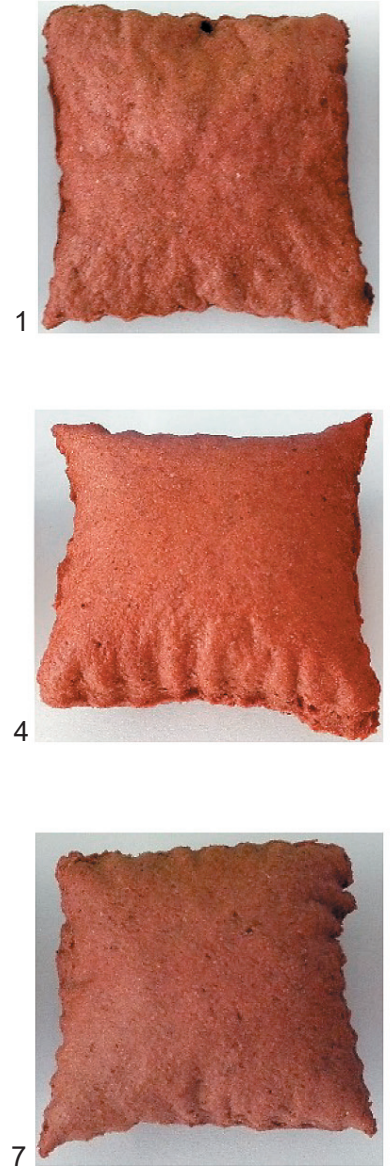

2
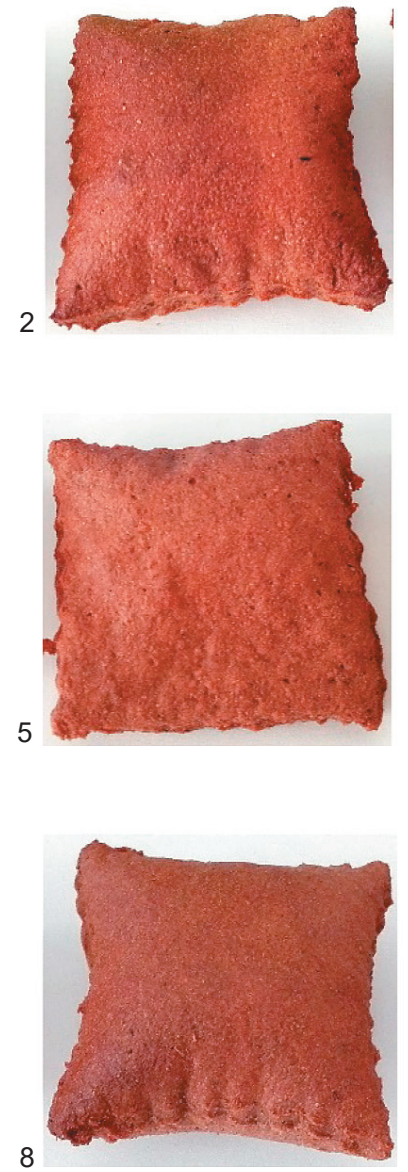
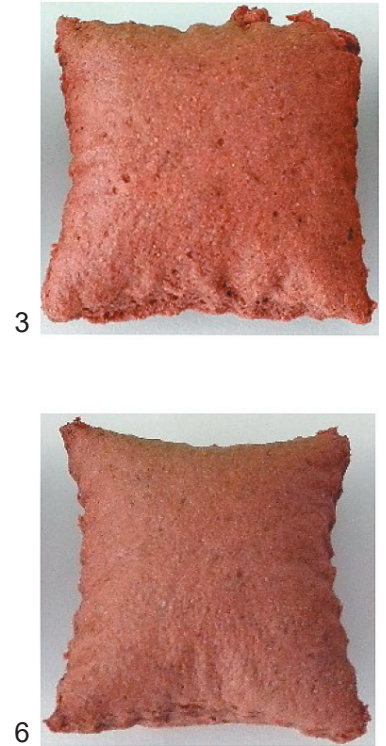

6

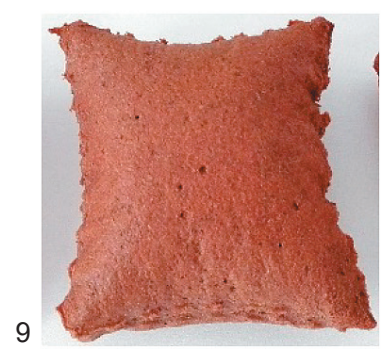

FIGURE 1. Model water biscuits made of buckwheat flour unfermented (1 - control) or fermented by: (2-4) L. acidophilus (145, La5, V, respectively); (5) L. casei LcY; (6-7) L. plantarum (W42, IB, respectively); (8) L. rhamnosus 8/4, and (9) L. salivarius AWH.

(55.5 and $45.3 \mathrm{~N}$, respectively), while the other freshly examined biscuits did not differ significantly $(\mathrm{p}>0.05)$ in hardness values. Significantly greater differences in hardness values of the analyzed biscuits were noted after 24-h storage in plastic bags at room temperature. The hardness of stored biscuits was lower compared to the fresh ones. The highest values were obtained for the biscuits made of buckwheat flour fermented by $L$. acidophilus $\mathrm{V}$ and $L$. plantarum $\mathrm{W} 42$ (45.5 and $40.3 \mathrm{~N}$, respectively). Whereas, the lowest hardness after $24 \mathrm{~h}$ of storage was found for the control biscuits $(4.3 \mathrm{~N})$ and for the biscuits prepared from buckwheat flour fermented by L. acidophilus La5 $(4.5 \mathrm{~N})$. It should be noted, however, that in the case of the biscuits made of buckwheat flour fermented by L. acidophilus $\mathrm{V}$ and L. plantarum $\mathrm{W} 42$ there were no statistically significant differences $(\mathrm{p}>0.05)$ in hardness of the fresh and stored samples. The provided results are in accordance to the recent evidences confirming that the addition of buckwheat flour increases the hardness of food products. Filipčev et al. [2011] showed that buckwheat flour used for making biscuits caused an increase of their hardness, whereas rye flour showed an opposite effect. Also Bilgiçli \& İbanoğlu [2015] observed that the highest ratios of buckwheat flour in wheat bread adversely affected its hardness values.

One of the main properties of a food product assessed by consumers is its color, which is the first quality criterion of a food product for consumers. Generally, the analyzed biscuits made of the fermented flours were lighter compared to the control sample (Table 3). Lower or comparable values of $L^{*}, b^{*}$ and $\Delta E$ were noticed only for the biscuits prepared from buckwheat flour fermented by L. plantarum IB. Also the $\mathrm{a}^{*}$ and $\mathrm{b}^{*}$ values were significantly higher in all analyzed biscuits compared to the control ones $(p<0.05)$. Values of color parameters obtained in this study are lower compared to our previous findings made for buckwheat groats [Wronkowska et al., 2016], where the $\mathrm{L}^{*}, \mathrm{a}^{*}, \mathrm{~b}^{*}$, and $\Delta \mathrm{E}$ values reached: $83,3,9$, and 84 , respectively, in raw groats. But after roasting at $160^{\circ} \mathrm{C}$, values of all these color parameters decreased significantly, reaching: $58,11,23$, and 63 , respectively. Bilgiçli [2009] explains the darkening tarhana (traditional fermented cereal food) supplemented with buckwheat flour by degradation of phytic acid during fermentation, which causes an increase in free minerals content. After the fermentation process, free minerals catalyze some non-enzymatic browning reactions, which evokes sample darkening.

The browning index (BI) of biscuits made of the fermented buckwheat flours was generally higher compared to the control sample (Table 3). The highest value of BI was noticed for biscuits prepared from buckwheat flour fermented by $L$. plantarum IB and the lowest one for the control sample (27.7 and 21.8, respectively). The browning index could be used to quantify the color change attributed to caramelization and Maillard reactions [Isleroglu et al., 2012]. 
TABLE 3. Color and browning index of model water biscuits made of buckwheat flour fermented by selected strains of lactic acid bacteria.

\begin{tabular}{|c|c|c|c|c|c|}
\hline \multirow{2}{*}{ Sample } & \multicolumn{5}{|c|}{ Color } \\
\hline & $\mathrm{L}^{*}$ & $a^{*}$ & $b^{*}$ & $\Delta \mathrm{E}$ & BI \\
\hline Control & $42.17 \pm 4.07^{\mathrm{c}}$ & $10.52 \pm 1.01^{\mathrm{b}}$ & $18.67 \pm 2.56^{\mathrm{b}}$ & $47.32 \pm 4.78^{\mathrm{bc}}$ & $21.80 \pm 0.88^{\mathrm{e}}$ \\
\hline L. plantarum IB & $38.21 \pm 4.67^{\mathrm{d}}$ & $12.58 \pm 1.21^{\mathrm{a}}$ & $18.78 \pm 3.14^{\mathrm{b}}$ & $44.43 \pm 5.51^{\mathrm{c}}$ & $27.69 \pm 2.13^{\mathrm{a}}$ \\
\hline L. plantarum W42 & $46.65 \pm 2.95^{\mathrm{a}}$ & $12.38 \pm 0.80^{\mathrm{a}}$ & $21.77 \pm 1.23^{\mathrm{a}}$ & $52.95 \pm 3.18^{\mathrm{a}}$ & $23.13 \pm 0.85^{\mathrm{d}}$ \\
\hline L. casei $\mathrm{LcY}$ & $46.80 \pm 3.00^{\mathrm{a}}$ & $12.85 \pm 0.71^{\mathrm{a}}$ & $22.44 \pm 0.82^{\mathrm{a}}$ & $53.48 \pm 3.10^{\mathrm{a}}$ & $23.88 \pm 0.65^{\mathrm{bcd}}$ \\
\hline L. acidophilus La5 & $46.13 \pm 4.31^{\mathrm{ab}}$ & $12.90 \pm 0.50^{\mathrm{a}}$ & $22.42 \pm 0.88^{\mathrm{a}}$ & $52.91 \pm 4.07^{\mathrm{a}}$ & $24.41 \pm 1.95^{\mathrm{bcd}}$ \\
\hline L. acidophilus V & $43.52 \pm 1.93^{\mathrm{bc}}$ & $12.77 \pm 0.42^{\mathrm{a}}$ & $22.02 \pm 0.31^{\mathrm{a}}$ & $50.43 \pm 1.63^{\mathrm{ab}}$ & $25.45 \pm 1.65^{\mathrm{b}}$ \\
\hline L. acidophilus 145 & $44.71 \pm 1.77^{\mathrm{abc}}$ & $12.83 \pm 0.46^{\mathrm{a}}$ & $22.37 \pm 0.45^{\mathrm{a}}$ & $51.63 \pm 1.37^{\mathrm{a}}$ & $24.97 \pm 1.64^{\mathrm{bc}}$ \\
\hline L. rhamnosus $8 / 4$ & $43.55 \pm 2.40^{\mathrm{bc}}$ & $12.33 \pm 0.76^{\mathrm{a}}$ & $21.22 \pm 0.98^{\mathrm{a}}$ & $46.97 \pm 5.92^{\mathrm{bc}}$ & $24.55 \pm 1.60^{\mathrm{bcc}}$ \\
\hline L. salivarius AWH & $45.41 \pm 1.26^{\mathrm{ab}}$ & $12.22 \pm 0.57^{\mathrm{a}}$ & $21.83 \pm 0.98^{\mathrm{a}}$ & $47.41 \pm 6.34^{\mathrm{bc}}$ & $23.56 \pm 1.70^{\text {cd }}$ \\
\hline
\end{tabular}

Data expressed as mean \pm standard deviation. Values followed by the same letter in the same column (a-e) are not significantly different ( $\mathrm{p}>0.05$ ). $\mathrm{L}^{*}$, lightness; $\mathrm{a}^{*}$, redness; $\mathrm{b}^{*}$ yellowness; $\Delta \mathrm{E}$, color differences; $\mathrm{BI}$, browning index.

TABLE 2. Content of soluble proteins and hardness of model water biscuits made of buckwheat flour fermented by selected strains of lactic acid bacteria.

\begin{tabular}{l|c|c|c}
\hline \multirow{2}{*}{ Sample } & \multirow{2}{*}{$\begin{array}{c}\text { Soluble } \\
\text { proteins } \\
\text { (mg/g d.m. })\end{array}$} & \multicolumn{2}{|c}{ Hardness (N) } \\
\cline { 3 - 4 } & $41.05 \pm 0.23^{\mathrm{b}}$ & $37.06 \pm 6.99^{\mathrm{cA}}$ & $4.34 \pm 1.53^{\mathrm{dB}}$ \\
\hline Control & $45.25 \pm 0.36^{\mathrm{a}}$ & $55.47 \pm 7.60^{\mathrm{aA}}$ & $24.57 \pm 7.94^{\mathrm{bB}}$ \\
L. plantarum $\mathrm{IB}$ & $35.31 \pm 0.24^{\mathrm{d}}$ & $45.34 \pm 8.38^{\mathrm{bA}}$ & $40.27 \pm 3.53^{\mathrm{aA}}$ \\
L. plantarum $\mathrm{W} 42$ & $38.76 \pm 0.03^{\mathrm{c}}$ & $31.42 \pm 7.68^{\mathrm{cA}}$ & $9.57 \pm 2.65^{\mathrm{cdB}}$ \\
L. casei $\mathrm{LcY}$ & $43.00 \pm 0.27^{\mathrm{b}}$ & $37.75 \pm 9.19^{\mathrm{bcA}}$ & $4.48 \pm 2.01^{\mathrm{dB}}$ \\
L. acidophilus $\mathrm{La} 5$ & & & after $24 \mathrm{~h}$ \\
L. acidophilus $\mathrm{V}$ & $33.82 \pm 0.56^{\mathrm{d}}$ & $35.35 \pm 9.16^{\mathrm{cA}}$ & $45.49 \pm 9.89^{\mathrm{aA}}$ \\
L. acidophilus 145 & $37.84 \pm 0.22^{\mathrm{c}}$ & $33.14 \pm 5.49^{\mathrm{cA}}$ & $12.97 \pm 6.02^{\mathrm{cB}}$ \\
L. rhamnosus $8 / 4$ & $39.53 \pm 0.24^{\mathrm{c}}$ & $38.33 \pm 4.13^{\mathrm{bcA}}$ & $12.81 \pm 3.98^{\mathrm{cB}}$ \\
L. salivarius $\mathrm{AWH}$ & $35.29 \pm 0.25^{\mathrm{d}}$ & $35.89 \pm 7.41^{\mathrm{cA}}$ & $17.13 \pm 2.77^{\mathrm{cB}}$ \\
\hline
\end{tabular}

Data expressed as mean \pm standard deviation. Values followed by the same letter in the same column (a-d) or row (A, B) are not significantly different $(\mathrm{p}>0.05)$.

TABLE 4. Pearson's linear correlation coefficients (r) between $\Delta \mathrm{pH}$ or content of soluble protein and analyzed physical parameters of model water biscuits.

\begin{tabular}{l|c|c}
\hline Physical parameters & $\Delta \mathrm{pH}$ & $\begin{array}{c}\text { Content } \\
\text { of soluble } \\
\text { proteins }\end{array}$ \\
\hline $\mathrm{L}^{*}$ & 0.275 & -0.780 \\
$\mathrm{a}^{*}$ & 0.924 & 0.015 \\
$\mathrm{~b}^{*}$ & 0.657 & -0.663 \\
$\Delta \mathrm{E}$ & 0.253 & -0.562 \\
$\mathrm{BI}$ & 0.573 & 0.644 \\
Hardness of fresh samples & 0.079 & 0.772 \\
Hardness of samples after 24h of storage & 0.394 & -0.171 \\
\hline
\end{tabular}

$\mathrm{L}^{*}$, lightness; $\mathrm{a}^{*}$, redness; $\mathrm{b}^{*}$ yellowness; $\Delta \mathrm{E}$, colour differences; $\mathrm{BI}$, browning index.
The cited authors found a positive correlation between the browning index and acrylamide formation in cookies baked in different types of oven and at different temperatures. They showed that the browning index may be considered as a reliable indicator of acrylamide content in cookies. In turn, Di Cagno et al. [2011] found that lactic acid fermentation had a preservative effect on the color and browning index during the storage of red and green smoothies. The same positive observation was made by these authors in their another study with prickly pear fermented by lactic acid bacteria [Di Cagno et al., 2016].

The Pearson correlation analysis demonstrated a positive correlation between the soluble proteins content in fermented buckwheat flours and hardness $(r=0.722)$ and browning index $(r=0.644)$ of fresh water biscuits (Table 4). Interesting was the positive correlation between all analyzed color parameters and hardness value after 24-h storage with changes in $\mathrm{pH}$ of buckwheat flours fermented with selected lactic acid bacteria. Values of all color parameters were positively correlated with changes in flour $\mathrm{pH}$ during $24-\mathrm{h}$ fermentation: $L^{*}$ (lightness; $r=0.275$ ), $a^{*}$ (redness; $r=0.924$ ), $b^{*}$ (yellowness; $r=0.657$ ), $\Delta \mathrm{E}$ (color differences; $r=0.253$ ), and $\mathrm{BI}$ (browning index; $r=0.573$ ). There was also a positive correlation $(\mathrm{r}=0.394)$ between the hardness of water biscuits stored for $24 \mathrm{~h}$ and a change of $\mathrm{pH}$ during the fermentation of buckwheat flour. Significant acidification of the 5\% suspension of buckwheat flour during 24-hour fermentation affected the content of soluble proteins.

\section{CONCLUSION}

The effects of fermentation of buckwheat flour on some physical properties of biscuits were analyzed on the model of water biscuits. Eight strains of lactic acid bacteria, used in this study, caused no significant differences in the hardness of fresh buckwheat water biscuits. But significantly greater differences in the physical properties of biscuits were observed after storage. The analyzed water biscuits 
were lighter and had a higher browning index compared to the control sample. There were no negative changes observed in the analyzed properties of the buckwheat water biscuits under the influence of the selected strains of lactic acid bacteria.

\section{RESEARCH FUNDING}

This research was supported by grant No 2014/15/B/ NZ9/04461 from the National Science Centre, Poland.

\section{CONFLICT OF INTERESTS}

Authors declare no conflict of interests.

\section{REFERENCES}

1. AACC, American Association of Cereal Chemists. AACC Official Methods 10-52, Baking quality of cookie flour - micro method. Approved Methods of the American Association of Cereal Chemists ( $9^{\text {th }}$ ed.). 1995, Minneapolis, MN, USA: AACC.

2. Bilgiçli N., Effect of buckwheat flour on chemical and functional properties of tarhana. LWT - Food Sci. Technol., 2009, 42, 514-518.

3. Bilgiçli N., İbanoğlu S., Effect of pseudo cereal flours on some physical, chemical and sensory properties of bread. J. Food Sci. Technol., 2015, 52, 7525-7529.

4. Chavan U.D., Chavan J.K., Kadam S.S., Effect of fermentation on soluble proteins and in vitro protein digestibility of sorghum, green gram and sorghum-green gram blends. J. Food Sci., 1988, 53, 1574-1575.

5. Ciesarová Z., Basil E., Kukurová K., Marková L., Zieliński H., Wronkowska M., Gluten-free muffins based on fermented and unfermented buckwheat flour - content of selected elements. J. Food Nutr. Res., 2016, 55, 2, 108-113.

6. Coda R., Di Cagno R., Rizzello C.G., Nionelli L., Edema M.O., Gobbetti M., Utilization of African grains for sourdough bread making. J. Food Sci., 2011, 76, 329-335.

7. Coda R., Rizzello C.G., Gobbetti M., Use of sourdough fermentation and pseudo-cereals and leguminous flours for the making of a functional bread enriched of g-aminobutyric acid (GABA). Int. J. Food Microbiol., 2010, 137, 236-245.

8. Di Cagno R., Filannino P., Vincentini O., Lanera A., Cavoski I., Gobbetti M., Exploitation of Leuconostoc mesenteroides strains to improve shelf life, rheological, sensory and functional features of prickly pear (Opuntia ficus-indica L.) fruit puree. Food Microbiol., 2016, 59, 176-189.

9. Di Cagno R., Minervini G., Rizzello C.G., De Angelis M., Gobbetti M., Effect of lactic acid fermentation on antioxidant, texture, color and sensory properties of red and green smoothies. Food Microbiol., 2011, 28, 1062-1071.

10. Filipčev B., Šimurina O., Bodroža-Solarov M., Vujaković M., Evaluation of physical, textural and microstructural properties of dough and honey biscuits enriched with buckwheat and rye. Chem. Ind. Chem. Eng. Q., 2011, 17, 291-298.

11. Frias J., Miranda M.L., Doblado R., Vidal-Valverde C., Effect of germination and fermentation on the antioxidant vitamin content and antioxidant capacity of Lupinus albus L. var. Multolupa. Food Chem., 2005, 92, 211-220.
12. Gallagher E., Gormley T.R., Arendt E.K., Recent advanced in the formulation of gluten-free cereal-based products. Trends Food Sci. Technol., 2004, 15, 143-152

13. Giménez-Bastida J.A., Piskuła M.K., Zieliński H., Recent advances in development of gluten-free buckwheat products. Trends Food Sci. Technol., 2015b, 44, 58-65.

14. Giménez-Bastida J.A., Zieliński H., Buckwheat as a functional food and its effects on health. J. Agr. Food Chem., 2015a, 63, 7896-7913.

15. Hidalgo A., Brandolini A., Heat damage of water biscuits from einkorn, durum and bread wheat flours. Food Chem., 2011, 128, 471-478.

16. Horszwald A., Troszyńska A., del Castillo M. D., Zieliński H., Protein profile and sensorial properties of rye breads. Eur. Food Res. Technol., 2009, 229, 875-886.

17. Isleroglu H., Kemerli T., Sakin-Yilmazer M., Guven G., Ozdestan O., Uren A., Kaymak-Ertekin F., Effect of steam baking on acrylamide formation and browning kinetics of cookies. J. Food Sci., 2012, 77, E257-E263.

18. Kocková M., Dilongová M., Hybenová E., Valík L., Evaluation of cereals and pseudocereals suitability for the development of new probiotic foods. J. Chem., 2013b, article ID 414303, 1-8, [http://dx.doi.org/10.1155/2013/414303].

19. Kocková M., Mendel J., Medvedová A., Šturdík E., Valík L., Cereals and pseudocereals as substrates for growth and metabolism of a probiotic strain Lactobacillus rhamnosus GG. J. Food Nutr. Res., 2013a, 52, 25-36.

20. Lopez A.C.B., Pereira A.J.G., Junqueira R.G., Flour mixture of rice flour, corn and cassava starch in the production of gluten-free white bread. Brazilian Arch. Biol. Technol., 2004, 47, 63-70.

21. Matejčeková Z., Liptáková D., Valík L., Functional probiotic products based on fermented buckwheat with Lactobacillus rhamnosus. LWT - Food Sci. Technol., 2017, 81, 35-41.

22. Mohammadi A., Shahin R., Zahra E.D., Alirez K., Kinetic models for colour changes in kiwi fruit slices during hot air drying. World J. Agric. Sci., 2008, 4, 376-383.

23. Muller M.R., Wolfrum G., Stolz P., Ehrmann M.A., Vogel R.F., Monitoring the growth of Lactobacillus species during a rye flour fermentation. Food Microbiol., 2001, 18, 217-227.

24. Ouoba L.I.I., Rechinger K.B., Barkholt V., Diawara B., Traore A.S., Jakobsen M., Degradation of proteins during the fermentation of African locust bean (Parkia biglobosa) by strains of $\mathrm{Ba}$ cillus subtilis and Bacillus pumilus for production of Soumbala. J. Appl. Microbiol., 2003, 94, 396-402.

25. Pelikánová J., Liptáková D., Valík L., Suitability of lactic acid bacteria for fermentation of maize and amaranth. J. Food Nutr. Res., 2015, 54, 354-364.

26. Santos C.C., Libeck B.S., Schwan R.F., Co-culture fermentation of peanut soy milk for the development of a novel functional beverage. Int. J. Food Microbiol., 2014, 186, 32-41.

27. Smith P.K., Krohn R.I., Hermanson G.T., Macia A.K., Gartner F.H., Provenzano M.D., Fujimoto E.K., Goeke N.M., Olson B.J., Klenk D.C., Measurement of protein using bicinchoninic acid. Anal. Biochem., 1985, 150, 76-85.

28. Wronkowska M., Haros M., Soral-Śmietana M., Effect of starch substitution by buckwheat flour on gluten-free bread quality. Food Bioprocess Technol., 2013, 6, 1820-1827.

29. Wronkowska M., Piskuła M.K., Zieliński H., Effect of roasting time of buckwheat groats on the formation of Maillard reac- 
tion products and antioxidant capacity. Food Chem., 2016, 196, 355-358.

30. Wronkowska M., Soral-Śmietana M., Krupa-Kozak U., Buckwheat, as a food component of a high nutritional value, used in the prophylaxis of gastrointestinal diseases. Eur. J. Plant Sci. Biotechnol., 2010, 4 (special issue 1), 64-70.
31. Yildiz Ö., Bulut B., Optimization of gluten-free tulumba dessert formulation including corn flour: response surface methodology approach. Pol. J. Food Nutr. Sci., 2017, 67, 25-31.

Submitted: 1 June 2017. Revised: 27 June and 7 September 2017. Accepted: 15 September 2017. Published on-line: 20 September 2017. 
